Erratum

\title{
Erratum: López-Ochoa, et al. Energy Renovation of Residential Buildings in Cold Mediterranean Zones Using Optimized Thermal Envelope Insulation Thicknesses: The Case of Spain. Sustainability 2020, 12,2287
}

\author{
Luis M. López-Ochoa *D, Jesús Las-Heras-Casas $\mathbb{D}$, Luis M. López-González (D) and \\ César García-Lozano \\ TENECO Research Group, Department of Mechanical Engineering, University of La Rioja, \\ 26004 Logroño, La Rioja, Spain; jesus.las-herasc@unirioja.es (J.L.-H.-C.); \\ luis-maria.lopez@unirioja.es (L.M.L.-G.); cesar.garcia@unirioja.es (C.G.-L.) \\ * Correspondence: luis-maria.lopezo@unirioja.es
}

Received: 6 November 2020; Accepted: 10 November 2020; Published: 18 November 2020

The authors would like to make the following corrections about the published paper [1]. The changes are as follows:

(1) Replacing the dot with a comma in following Equation (1) in Section 2.4.:

$$
U_{e}=\frac{1}{R_{e}}
$$

with

$$
U_{e}=\frac{1}{R_{e}}
$$

(2) Removing the dot after " $R_{e}$ " in the following sentence after Equation (1):

where $e$ corresponds to the walls, roof and first floor framework; $R_{e}$. corresponds to the thermal resistance of element $e$ of the building envelope, in $\mathrm{m}^{2} \cdot \mathrm{K} / \mathrm{W}$, and is calculated using the following equation:

with

where $e$ corresponds to the walls, roof and first floor framework; $R_{e}$ corresponds to the thermal resistance of element $e$ of the building envelope, in $\mathrm{m}^{2} \cdot \mathrm{K} / \mathrm{W}$, and is calculated using the following equation:

(3) Adding "unit of living area and" to the following sentence in Section 2.5 after Equation (13):

where $E D_{D H W}^{e x i s}$ is the average DHW energy demand per year for existing multi-family buildings built before 2008 (in the selected cities with the same climate zone and January climate zone), in $\mathrm{kWh} / \mathrm{m}^{2}$.year, obtained from the corresponding energy demands in [44]. with

where $E D_{D H W}^{e x i s}$ is the average DHW energy demand per unit of living area and year for existing multi-family buildings built before 2008 (in the selected cities with the same climate zone and January climate zone), in $\mathrm{kWh} / \mathrm{m}^{2}$ year, obtained from the corresponding energy demands in [44]. 
(4) Change in Equation (25):

$$
x_{o p t, e}^{\text {heat }}=\left(\frac{0.024 \cdot H D D \cdot C_{f u e l} \cdot P W F \cdot \lambda}{\eta}\right)^{0.5}-\lambda \cdot R_{e}^{\text {exis }}
$$

with

$$
x_{o p t, e}^{\text {heat }}=\left(\frac{0.024 \cdot H D D \cdot C_{f u e l} \cdot P W F \cdot \lambda}{C_{i n s u} \cdot \eta}\right)^{0.5}-\lambda \cdot R_{e}^{e x i s}
$$

(5) Replacing phrase "exchange surface" with "living area" to the following sentence in Section 2.6 after Equation (29):

The cost of the energy renovation of the building with an optimized insulation thickness that minimizes the total heating cost per unit of exchange surface, $C_{\text {heat }}^{\text {reno }}$, in $€ / \mathrm{m}^{2}$, is calculated with the following equation:

with

The cost of the energy renovation of the building with an optimized insulation thickness that minimizes the total heating cost per unit of exchange surface, $C_{\text {heat }}^{\text {reno }}$, in $€ / \mathrm{m}^{2}$, is calculated with the following equation:

(6) Replacing phrase "exchange surface" with "living area" to the following sentence in Section 2.6 after Equation (30):

The total net savings for the renovated building with an optimized insulation thickness that minimizes the total heating cost per unit of exchange surface, $E C S_{\text {heat }}^{\text {reno }}$, in $€ / \mathrm{m}^{2}$.year, is calculated using the following equation:

with

The total net savings for the renovated building with an optimized insulation thickness that minimizes the total heating cost per unit of living area, $E C S_{\text {heat }}^{\text {reno }}$, in $€ / \mathrm{m}^{2} \cdot$ year, is calculated using the following equation:

(7) Change Equation (33):

$$
x_{\text {opt }, e}^{\text {heat }+ \text { cool }}=\left(\frac{0.024 \cdot H D D \cdot C_{f u e l} \cdot P W F \cdot \lambda}{\eta}+\frac{0.024 \cdot C D D \cdot C_{\text {elec }} \cdot P W F \cdot \lambda}{\varepsilon}\right)^{0.5}-\lambda \cdot R_{e}^{\text {exis }} .
$$

with

$$
x_{o p t, e}^{\text {heat }+ \text { cool }}=\left(\frac{0.024 \cdot H D D \cdot C_{f u e l} \cdot P W F \cdot \lambda}{C_{\text {insu }} \cdot \eta}+\frac{0.024 \cdot C D D \cdot C_{\text {elec }} \cdot P W F \cdot \lambda}{C_{\text {insu }} \cdot \varepsilon}\right)^{0.5}-\lambda \cdot R_{e}^{\text {exis }} .
$$

The authors and the Editorial Office would like to apologize for any inconvenience caused to the readers by these changes. The changes does not affect the scientific results. The manuscript will be updated and the original will remain online on the article webpage. 


\section{Reference}

1. López-Ochoa, L.M.; Las-Heras-Casas, J.; López-González, L.M.; García-Lozano, C. Energy Renovation of Residential Buildings in Cold Mediterranean Zones Using Optimized Thermal Envelope Insulation Thicknesses: The Case of Spain. Sustainability 2020, 12, 2287. [CrossRef]

Publisher's Note: MDPI stays neutral with regard to jurisdictional claims in published maps and institutional affiliations.

(C) 2020 by the authors. Licensee MDPI, Basel, Switzerland. This article is an open access article distributed under the terms and conditions of the Creative Commons Attribution (CC BY) license (http://creativecommons.org/licenses/by/4.0/). 